\title{
Poznan Project Projekt indeksacji małżeństw z Wielkopolski dla lat 1800-1899
}

Rozwój metod komputerowych w latach dziewięćdziesiątych i ogólnoświatowa sieć Internet otworzyły zupełnie nowe horyzonty w genealogii. Gromadzenie, przetwarzanie i przesyłanie ogromnych ilości danych cyfrowych dostępnych, przynajmniej potencjalnie, mieszkańcom całego globu w domowym zaciszu umożliwia formy aktywności nieznane badaczom z poprzednich dziesięcioleci. Przedsięwzięcie opisywane w niniejszym artykule udowodniło, że współpraca licznych hobbystów poszukiwań historii rodziny, wspomaganych komunikacją internetową i przy coraz większej dostępności cyfrowych materiałów źródłowych, pozwala w rezultacie stworzyć potężne narzędzie ułatwiające pracę genealogom na całym świecie, w tym wypadku ogromną bazę danych wraz z wygodną darmową wyszukiwarką umieszczoną w sieci.

Historia Poznan Project sięga roku 1999, kiedy na bazie dyskusji internetowych w gronie polskich i amerykańskich pasjonatów odkrywania korzeni rodzinnych padła propozycja spisania danych o ślubach mieszkańców Wielkiego Księstwa Poznańskiego w okresie poprzedzającym falę emigracji zarobkowej z tego obszaru, mającej za cel głównie Stany Zjednoczone, ale i zachodnie regiony Niemiec, Francję, Australię, Brazylię oraz w mniejszym stopniu inne kraje. Powszechnym problemem, z jakim zmagają się osoby szukające miejsca pochodzenia imigrantów do USA, jest stosowanie określenia Poznań czy też (za językiem niemieckim) Posen w znaczeniu całej Prowincji Poznańskiej (Wielkiego Księstwa). W języku polskim stosowano tu potoczne określenie „Poznańskie”, jednak po angielsku i niemiecku nazwa miasta i prowincji zapisywana jest w zasadzie identycznie, co nieraz sprowadza poszukiwania na fałszywe tory (sugerując miasto Poznań jako miejscowość po- 
chodzenia imigrantów mających „Posen” wpisane do dokumentów podróżnych i innych, wystawionych już w kraju docelowym). Osoby zaś, które zdają sobie sprawę z faktu, iż określenie „Posen” odnosi się raczej do całej prowincji, a nie do miasta, muszą dojść do wniosku, że odszukanie przodka w dokumentach metrykalnych wielu setek wielkopolskich parafii jest zadaniem niewykonalnym w pojedynkę.

Rozwiązanie polegające na wspólnym zindeksowaniu ślubów z całego regionu i udostępnieniu ich $\mathrm{w}$ formie bazy danych, dawało zatem nadzieję na odszukanie w przyszłości każdej pary, która na tym terenie zawarła małżeństwo, wraz z informacją o czasie i miejscu ślubu. Dane powyższe pozwalają na ogół na skuteczną kontynuację badań historii rodziny już na gruncie wielkopolskim. Dla podjętego projektu przyjęto angielską nazwę Poznan Project, co ściśle rzecz biorąc należałoby przetłumaczyć jako „Projekt Poznańskie”, sens tej nazwy zawierał się w postulacie opracowania całej pruskiej Prowincji Poznańskiej, a jednocześnie wyeksponowana została nazwa „Poznań, której dwuznaczność leżała wszak u źródła omawianego problemu. Można było zakładać, że w przeciętnej parafii odbywało się rocznie około kilku do kilkunastu ślubów, których spisanie w skali lat kilkudziesięciu lub nawet całego stulecia nie przekraczałoby możliwości jednej osoby. Pozostało więc zebranie grona ochotników, którzy chcieliby poświęcić czas na współpracę w tak zarysowanym projekcie. Koordynacji działań podjął się Łukasz Bielecki z Poznania.

Początkowo prace indeksacyjne, wykonywane głównie przez genealogów polonijnych, przebiegały dość powoli, zwłaszcza że trzeba było równocześnie szczegółowo rozpoznać istniejące źródła, którymi są dla Poznan Project przede wszystkim dziewiętnastowieczne księgi ślubów parafii katolickich i ewangelickich, w mniejszym stopniu ich cywilne duplikaty (w okresie 1808-1874) i akta pruskich urzędów stanu cywilnego (od 1 października 1874 r.).

W roku 1999 przyjęliśmy zakres lat 1835-1884 jako ten, dla którego należy w miarę możliwości zindeksować komplet ślubów - było to pięćdziesięciolecie poprzedzające okres najbardziej intensywnej emigracji. $\mathrm{W}$ takim przedziale czasu, jak można było założyć, z każdej rodziny powinno dać się odszukać ślub przynajmniej w jednym pokoleniu. Następnie zakres ten był jeszcze dwukrotnie rozszerzany i ostatecznie obejmuje lata 1800-1899. Również terytorialnie poszerzono obszar działania Projektu, pierwotny teren pruskiej Prowincji Poznańskiej uzupełniono o inne regiony wchodzące w skład szeroko rozumianej historycznej Wielkopolski, szczególnie o gubernię kaliską $\mathrm{w}$ granicach z zaboru rosyjskiego, rejon Wałcza i Złotowa oraz liczne parafie przyległe.

Przełomem w pracach nad Projektem było włączenie się do jego realizacji w roku 2005 Macieja Głowiaka, który od podstaw stworzył bazę danych i wyszukiwarkę działającą od tej pory w Internecie. Możliwość wygodnego 
przeszukiwania dotychczas pozyskanych spisów ślubów zachęciła liczne dalsze grono ochotników spisujących dane, wśród których zdecydowaną przewagę uzyskali odtąd genealodzy polscy, zwłaszcza z kręgu Wielkopolskiego Towarzystwa Genealogicznego „Gniazdo”. Bez wątpienia indeksy sporządzone przez osoby dobrze znające język polski (zwłaszcza jako ojczysty) charakteryzują się znacznie mniejszą liczbą błędów. Podobnie zresztą ochotnicy niemieckojęzyczni zaczęli coraz liczniej wspomagać Projekt w zakresie spisywania danych $\mathrm{z}$ ksiąg ewangelickich, gdzie mamy do czynienia $\mathrm{z}$ trudnym dla dzisiejszego użytkownika dawniejszym pismem niemieckim (tzw. ręcznym gotykiem).

W okresie od uruchomienia wyszukiwarki (luty 2006 r.) do dziś liczba ślubów zebranych w bazie danych wzrosła z około 30 tysięcy od 1,2 miliona, czyli czterdziestokrotnie. W chwili obecnej posiadamy już dane o zdecydowanej większości ślubów katolickich zawartych na obszarze Wielkopolski w XIX wieku, a także o około połowie ślubów ewangelickich (stopień zniszczenia akt ewangelickich w konsekwencji II wojny światowej jest, niestety, znacząco wyższy). Prace nad spisywaniem ślubów cywilnych z lat 1874-1899 zaczęły się dość niedawno i do tej pory zindeksowano ich prawdopodobnie około kilkunastu procent istniejącego zasobu.

$\mathrm{W}$ ostatnich kilku latach zostały uruchomione liczne projekty digitalizacji metrykaliów polskich z przeznaczeniem do publikacji w Internecie (przede wszystkim są to działania koordynowane przez Narodowe Archiwum Cyfrowe przy uczestnictwie Archiwów Państwowych w całym kraju, materiały zaś są umieszczone $\mathrm{w}$ sieci pod adresem: szukajwarchiwach.pl). Dostępność skanów z terenów, które obejmuje nasz Projekt, sytuuje się zdecydowanie powyżej średniej krajowej, co pozwoliło m.in. na efektywne zindeksowanie metrykaliów z okolic Konina i Kalisza.

Zasadniczym założeniem Projektu od początku było zebranie z przyjętego zakresu lat i terytorium możliwie wszystkich zawartych ślubów, co pozwoli na odnalezienie $w$ bazie danych jak największego odsetka dawnych mieszkańców Wielkopolski. W związku z tym działania osób uczestniczących w Projekcie nie ograniczają się do indeksowania materiałów stosunkowo łatwo osiągalnych w Internecie bądź w archiwach, ale wymagają niekiedy odszukania i dotarcia do brakujących jeszcze ksiąg znajdujących się w nietypowych lub po prostu trudniej dostępnych miejscach przechowywania. Odnosi się to do parafii, lokalnych bibliotek, archiwów w Niemczech itp. Część metrykaliów dostępna jest na mikrofilmach znajdujących się w posiadaniu Kościoła Mormonów, z których można korzystać w sieci jego bibliotek na całym świecie (dwie lokalizacje w Polsce). Na mikrofilmach tych zdarzają się księgi już obecnie nieistniejące fizycznie. Odnalezienie i zebranie w jednej bazie danych informacji spisanych z tych wszystkich materiałów znacząco usprawnia poszukiwania rodzinne osób posiadających wielkopolskie korzenie. 
Zgromadzenie $\mathrm{w}$ jednym miejscu niemal kompletnej bazy danych małżeństw z XIX w. z terenu Wielkopolski otwiera również nowe możliwości analizy statystycznej wszystkich danych i pozwala na sformułowanie interesujących wniosków. Oprócz podstawowego celu - odnajdywania zapisów o ślubach w dziewiętnastowiecznej Wielkopolsce, baza danych tej wielkości (obejmująca szacunkowo prawie dwa miliony osób) może być przydatna w innych zastosowaniach z dziedzin: historii, demografii, językoznawstwa, antroponimii itp. I tak, dla przykładu, przebieg liczby zawieranych małżeństw $\mathrm{w}$ poszczególnych latach obrazuje występujące w Wielkopolsce epidemie. Widoczny spadek liczby ślubów przypada również na wojnę prusko-francuską, co wiąże się z poborem młodych mężczyzn do wojska. Po epidemiach i po wojnie następuje natomiast szybki wzrost liczby ślubów, z których duża część dotyczy powtórnych małżeństw wdowców i wdów. Dokładniejsza analiza danych pozwala również na ustalenie średniego wieku małżonków lub częstości występowania imion i nazwisk w poszczególnych częściach Wielkopolski, co można będzie w przyszłości zobrazować na mapie.

Baza danych i wyszukiwarka Projektu umieszczona jest na serwerach udostępnionych nam przez Poznańskie Centrum Superkomputerowo-Sieciowe pod adresem: poznan-project.psnc.pl. Wyszukiwarka posiada stworzony przez autorów, zaawansowany algorytm znajdowania podobieństw pisowni i brzmienia nazwisk. Jego stosowanie jest niezbędne dla odnalezienia możliwie największej liczby osób używających konkretnego nazwiska. Zawartość bazy danych z różnych przyczyn nie zawsze odpowiada informacji oczekiwanej przez użytkowników. Dziewiętnastowieczne akta metrykalne bowiem charakteryzują się niejednolitą pisownią tych samych nazwisk, których brzmienie nie było wówczas zresztą jeszcze do końca ustalone, zwłaszcza w odniesieniu do szerokich warstw ludności chłopskiej. Przy przedsięwzięciu o tej skali nie da się również uniknąć błędów odczytu przez indeksujących, a jakość materiału źródłowego też pozostawia nieraz wiele do życzenia. Dla poprawy odczytu stosujemy często korektę dokonywaną przez bardziej doświadczonych ochotników, najlepiej tych, którzy dobrze znają dany teren czy parafię.

Wyszukiwarka Poznan Project pozwala odnaleźć podstawowe informacje o ślubujących, spisane $\mathrm{w}$ przyjętym przez nas standardowym formacie, który ma za zadanie zasadniczo tylko identyfikację danej pary i odesłanie do oryginalnego aktu ślubu w odpowiednim archiwum (rzadziej innego typu lokalizacji). Nie daje bezpośredniego dostępu do skanu (większość spisanych w Projekcie ślubów i tak nie jest osiągalna w Internecie) i nie przytacza pełnego brzmienia zawartości aktu. Wyniki wyszukiwania nie są zatem samoistnym rezultatem badawczym, ale pomagają odnaleźć konkretne źródło historyczne, które użytkownik powinien następnie samodzielnie odszukać i krytycznie zanalizować. 
$\mathrm{W}$ podsumowaniu warto wspomnieć, że $\mathrm{w}$ kilkunastoletniej historii Poznan Project $w$ jego pracach (głównie przy spisywaniu danych) wzięło już udział około 350 osób, które poświęciły mu swój czas liczony niejednokrotnie w setkach, a może nawet tysiącach godzin. Niektórzy dostarczyli po około 50 tysięcy spisanych małżeństw. Uczestnicy pochodzą z kilkunastu krajów, głównie z Polski, Niemiec i USA. Od wielu miesięcy dzienna liczba zapytań do bazy sytuuje się między dwoma a trzema tysiącami i można zakładać, że wyszukiwarka ma setki użytkowników stałych i tysiące korzystających z niej sporadycznie. Na mapie podobnych inicjatyw Poznan Project ma już utrwaloną markę, co można stwierdzić, nawet pobieżnie przeszukując zasoby Internetu.

Łukasz Bielecki, Maciej Głowiak

\title{
Poznan Project \\ Projekt indeksacji małżeństw z Wielkopolski dla lat 1800-1899
}

\section{Streszczenie}

Poznan Project, prowadzony przez Wielkopolskie Towarzystwo Genealogiczne "Gniazdo" działa od roku 2000 i ma na celu zindeksowanie akt małżeństw z terenu Wielkopolski i Kujaw dla zakresu lat 1800-1899. Prace indeksacyjne prowadzą wolontariusze.

Na początkowym etapie prac ograniczono się się do terenu Wielkiego Księstwa Poznańskiego (zabór pruski), jednak później zakres terytorialny Projektu objął również część Wielkopolski znajdującą się w XIX w. pod zaborem rosyjskim (powiaty: Słupca, Konin, Koło, Kalisz, Turek), jak też inne regiony związane historycznie z Wielkopolską (Wałcz, Złotów) i przylegające obszary pograniczne (Tuchola, Radziejów, Sieradzkie). Z tak określonego terytorium udało się już zindeksować znaczną większość ślubów zapisanych w dziewiętnastowiecznych księgach metrykalnych i aktach Urzędów Stanu Cywilnego. Zostały one umieszczone w bazie danych, dla której od lutego 2006 r. funkcjonuje wyszukiwarka, dostępna online. W tym okresie dziesiątki tysięcy osób z kraju i zagranicy odnalazły w bazie informacje o lokalizacji akt małżeństw swych przodków. Wielu genealogom, głównie potomkom emigrantów z Poznańskiego, dane odnalezione w Poznan Project pozwoliły w ogóle ustalić miejscowość pochodzenia interesujących ich osób.

\section{The Poznan Project - the project for cataloging marriage acts from the years 1800-1899}

\begin{abstract}
The Greater Poland Genealogy Association "Gniazdo" has operated the Poznań Project since 2000. The aim of the project is to catalog marriage certificates issued in Wielkopolska and Kujawy regions between 1800 and 1899. The cataloging works are conducted by volunteers.
\end{abstract}


In the initial phase of the project, only the area of the Grand Duchy of Poznan (under Prussian occupation) was covered. Later, the scope of the project extended and included the part of Greater Poland which in the $19^{\text {th }}$ century was under the Russian occupation (the following districts: Słupca, Konin, Koło, Kalisz, Turek), other regions that have historically been associated with Greater Poland (Wałcz, Złotów), as well as the bordering areas (Tuchola, Radziejów, Sieradzkie). It was possible to catalog the majority of marriage certificates entered in the $19^{\text {th }}$-century books and registers of the registry offices from these areas. These certificates were entered into a database, which was made available online in February, 2006. Since then, tens of thousands of people from Poland and abroad managed to find information about the location of their ancestors' marriage certificates. Many genealogy specialists (mainly ancestors of the emigrants from the Poznan Duchy) managed to establish the origination of the people they were interested in, owing to the data found in the Poznan Project database. 